\title{
Ornithine in chronic migraine therapy and allodynia pattern: comparison with dopaminergic activation
}

\author{
M Nicolodi", M Nicolodi \\ From The European Headache and Migraine Trust International Congress \\ London, UK. 20-23 September 2012
}

Glutamate is converted to ornithine. Many enzyme reactions are involved in the inter-conversion of glutamate and ornithine by intestinal mucosa [1]. The modulation of the conversion might be a target in the final modulation of glutamatergic transmission. Since ornithine synthesis depends on glutamate, a larger amount of ornithine can explicate a feedback limiting effect on glutamatergic availability. A possible limited glutamatergic availability is here compared with a dopaminergic activation obtained by means of amantadine. In fact, both limited glutamatergic action and increased dopaminergic activity have been indicated to be crucial in analgesia determined at the level of anterior cingulate cortex (ACC) [2]. Experiences in chronic Migraine (M) therapy: in 107 chronic $M$ sufferers (69 females, 38 males, mean age $33.8+4.1 \mathrm{SD}$ ) ornithine (500 $\mathrm{mg}$ twice a day for 3 months) induced an amelioration paralleling the amantadine induced-relief (100 mg amantadine/day for 3 months). Indeed, both the active compounds induced a decrease of the attacks of $40 \% p>0.001$ versus 30-days wash-out and 30-days run-in periods A 14-days treatment induced a decrease $(\mathrm{p}>0.0001)$ of visceral/vascular hyperalgesia/allodynia rating $-65 \%$ in a $0-10$ VAS when comparing baseline values with the ones after both amantadine and ornithine administered in the aforementioned doses. These results suggest: a) that ornithine may act in the inteconversion of glutamate in all the tissues. Moreover, large doses of ornithine may induce a negative feedback in the mentioned interconversion. b) Dopaminergic and glutamatergic transmission, having opposite activity in pain processing in the ACC, that, in is turn, seems to have a crucial structure in pain

Foundation Prevention and Therapy Primary Pain, Italy dyshomeosthasis, seemingly act on the central mechanisms of chronic M.

Published: 21 February 2013

\section{References}

1. Jones E: Conversion of glutamate to ornithine and proline: pyrroline5 -carboxylate, a possible modulator of arginine requirements. The $J$ of Nutrition 1985, 115(4):509-515.

2. Lopez Avila A, Coffen U, Ortega Legaspi JM, Rosendo de Angel L, Pellicer F: Dopamine and NMDA systems modulate long-term nociception in the anterior cingulate cortex. Pain 2004, 111(1-2):136-149.

\section{doi:10.1186/1129-2377-14-S1-P189}

Cite this article as: Nicolodi and Nicolodi: Ornithine in chronic migraine therapy and allodynia pattern: comparison with dopaminergic activation. The Journal of Headache and Pain 2013 14(Suppl 1):P189.

Submit your manuscript to a SpringerOpen ${ }^{\odot}$ journal and benefit from:

- Convenient online submission

- Rigorous peer review

- Immediate publication on acceptance

- Open access: articles freely available online

- High visibility within the field

- Retaining the copyright to your article

Submit your next manuscript at $>$ springeropen.com (c) 2013 Nicolodi and Nicolodi; licensee Springer. This is an Open Access article distributed under the terms of the Creative Commons Attribution License (http://creativecommons.org/licenses/by/2.0), which permits unrestricted use, distribution, and reproduction in any medium, provided the original work is properly cited. 